\title{
La voz de las piedras. Las esculturas de San Agustín en el Museo Etnológico de Berlín
}

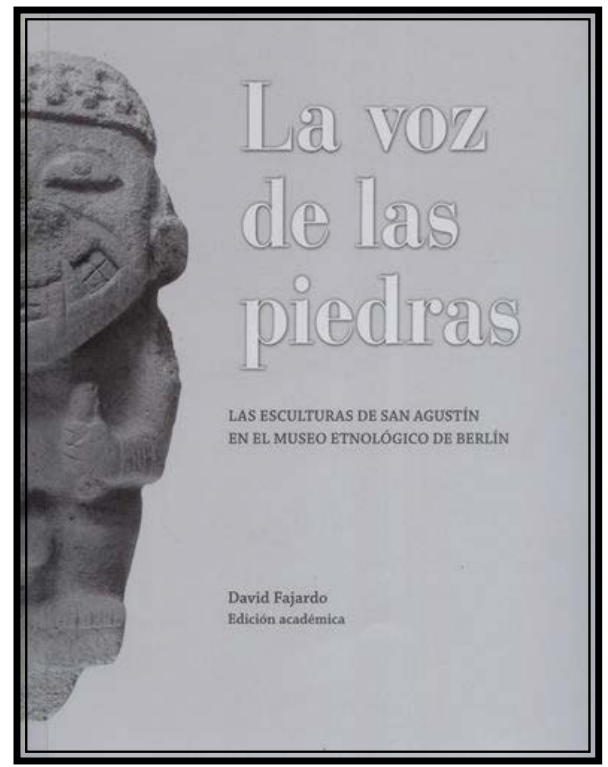

David Fajardo (2015). La voz de las piedras. Las esculturas de San Agustín en el Museo Etnológico de Berlín. Edición académica. Bogotá: Instituto Colombiano de Antropología e Historia ICANH.

Este catálogo fue elaborado con la intención de darle voz e imagen a las esculturas de San Agustín que han estado en el Museo Etnológico de Berlín por cerca de noventa años. No es mucha la información que se tiene al respecto y esta es la razón por la que este trabajo resulta de suma importancia. El registro fotográfico fue realizado con el fin de observar el estado actual en el que se encuentran las esculturas. Durante esos noventa años no había sido posible presentar de manera completa los elementos de piedra que Konrad Theodor Preuss recolectó durante sus investigaciones en Colombia.

Con el ánimo de presentar la información de las piezas, se hizo una descripción de cada una de ellas de la siguiente manera; en primer lugar, aparece el nombre que fue atribuido por Preuss a la figura; en caso de tenerlo, se utilizan las palabras que el autor utilizó para describirla. Después, se encuentra el código que le fue asignado en el Museo Etnológico de Berlín. Posterior el lugar de procedencia de la pieza, incluyendo municipio y departamento. El nombre de la colección a la que pertenece y, para finalizar, se presentan las medidas de cada una de las piezas.
Como anexo a este documento, se encuentra una versión facsimilar de ocho de las fichas de ingreso que Konrad Theodore Preuss realizó con su puño y letra para el registro de los elementos que llevó consigo a Berlín. En estas fichas se registró el sitio de procedencia de los objetos, el material, algunas medidas y un dibujo o fotografía de las piezas.

Es un placer para el Instituto Colombiano de Antropología e Historia (ICANH) presentar ante los investigadores, la ciudadanía colombiana y el gran público, las imágenes de las piezas del Alto Magdalena colombiano que se encuentran en el Museo Etnológico de Berlín, correspondientes a la cultura agustiniana, que trasladara Konrad Theodor Preuss a Alemania en los años posteriores a 1913.

Antes de lanzar cualquier juicio lesivo contra Preuss es inminente situar al investigador en su contexto histórico, dado que en la época del célebre etnólogo se daría el auge de los grandes 
coleccionistas que, pretendiendo constituir un 'archivo documental de la humanidad', buscaban una comprensión completa del mayor número de culturas a través de la acumulación de objetos de todas las latitudes.

De tal empresa participaría la Alemania imperial entre las demás potencias europeas, y lo que sería el Real Museo de Etnología para Alemania, lo fue también el Museo del Louvre para Francia, el British Museum para el Reino Unido y los Museos Vaticanos para las naciones de la península itálica. En consecuencia, esos templos del patrimonio de la humanidad se nutrieron para preservar y exhibir las piezas más representativas de todas las culturas del mundo, desde Mesoamérica hasta China, pasando por Australia y el Ártico, India, Mesopotamia y el Nilo, abarcando también el Alto Magdalena colombiano.

Ahora bien, desde el momento de su clasificación y documentación, fue reconocido por ambos Estados -Colombia y Alemania- que las piezas agustinianas que reposan en Berlín pertenecen al patrimonio arqueológico colombiano, las cuales han sido conservada y subsisten hasta la época gracias al cuidado del Museo Etnológico de Berlín, siguiendo su misión como institución científica. A ellos, en primer lugar, queremos darle nuestro agradecimiento, en particular a la antropóloga Manuela Fisher, quien ha sido responsable de la colección y nos ha permitido fotografiar las piezas para realizar este catálogo.

En segundo lugar, extendemos nuestro agradecimiento a Bárbara Göbel, directora del Instituto Iberoamericano en Berlín; al doctor Hermann Parzinger, presidente de la Fundación del Patrimonio Cultural Prusiano; al embajador de Colombia en Alemania, Juan Mayr Maldonado, al embajador de Alemania en Colombia, Günter Kniess y a su agregado cultural Gunnar Schneider, quienes han permitido todos estos procesos de documentación y han estado en permanente relación e intercambio cultural con el ICAHN.

Asimismo, queremos darle un especial reconocimiento a Roberto Pineda Camacho, quien gentilmente contribuyó con un texto para este catálogo; a David Fajardo, quien fuera ganador de una beca del ICAHN para realizar este proyecto; a Edgar Guzmán y a Yomayra Puentes, quienes fotografiaron las piezas del mejor modo posible.

El presente catálogo es un compendio más completo y estético que busca presentar el inventario que el mismo Museo Etnológico de Berlín dispone en línea para libre acceso del público, de manera que la ciudadanía se aproxime a las piezas agustinianas que están en tan prestigiosa institución.

ParalelamenteelICAHN, asícomoelMinisterio de Cultura y la Cancillería de Colombia, estudian la viabilidad y conveniencia, de acuerdo con una exhaustiva contextualización histórica y jurídica, de reclamar o no dichas piezas al gobierno alemán. Empero, cabe señalar que dichos procesos son extensos y que lo que busca este catálogo es hacer una representación específica de los tamaños, materiales, dimensiones y proporciones concretas, para que no se corra el riesgo de desinformar a la sociedad sobre las piezas que allí reposan y que constituyen nuestro patrimonio, las cuales actualmente pueden catalogarse como embajadoras de Colombia en Alemania.

Todos somos conscientes de la importancia que tiene este patrimonio "don del padre que nos endeuda simbólicamente con la cultura". Es por ello que la impresión de este catálogo contribuye a celebrar y renovar las relaciones diplomáticas y lazos de cooperación con Alemania que, en un contexto histórico, han sabido nutrirse gracias a la preservación de estas piezas.

Es importante subrayar que las ideas contemporáneas de museo se encuentran en las antípodas de un coleccionismo que encerraba, atomizaba y cristalizaba un "todo cultural" en sus salas, y se ha preocupado más por entender las encrucijadas sociales que significan y resignifican las percepciones que se tienen de los más diversos patrimonios de la humanidad. En ese horizonte, el museo vive hoy en constante metamorfosis y sus piezas perviven: 
el patrimonio está más vivo que nunca y no es propiedad privada de un grupo específico, sino que es un legado que a todos nos identifica y concierne.

Ojalá que algún día pudiéramos los colombianos recrear, como lo hizo Orhan Pamuk, un Museo de la inocencia, donde los objetos guarden un momento perdido de nuestras vidas $\mathrm{y}$, como sucede con las almas de los muertos en algunas leyendas populares, cada hora de nuestra vida, una vez muerta, se encarne y se oculte en algún material. Allí permanecería cautiva para siempre, a menos que reencontremos ese objeto, y por medio de él la reconozcamos y llamemos, y entonces la vida vuelva a nosotros.

Fabián Sanabria

De la Presentación 